\title{
New Technologies on Mine Process Tailing Disposal
}

\author{
Bascetin A., Tuylu S., Adıguzel D., and Ozdemir O. \\ Mining Engineering Department, Engineering Faculty, Istanbul University, Istanbul 34413, Turkey
}

\begin{abstract}
Tailings are formed as a result of mine processing. When these tailings are left in an environment in an inappropriate manner, they create a danger against the environment and human health. Therefore, the safe disposal of mine tailings above the ground is environmentally quite important. Today, tailing dams are generally used in the disposal of these mine tailings. However, this method has many environmental disadvantages such as AMD (acid mine drainage), heavy metal mobilization etc. For this reason, the use of alternative methods such as surface paste tailing disposal or geotextile methods are gradually increasing in the world. In this study, the advantages and disadvantages of the surface paste tailing disposal method and tailing disposal method using geotextile material compared to the traditional tailing dam method were evaluated in detail, and, the costs of these three methods for a typical Pb-Zn mine establishment were compared. The analysis indicated that the unit costs of the tailing dam, the surface disposal method, and the geotextile method were calculated as 2.25 \$/ton, 2.29 \$/ton, and 7.39 \$/ton, respectively. However, the unit price of surface paste disposal method become 2.79 \$ton when cement was used. The higher cost of the unit price of the tailing disposal method using geotextile method was attributed to the high cost of geotextile material.
\end{abstract}

Key words: Mine tailing, tailing dam, surface paste disposal, geotextile material.

\section{Introduction}

Great amounts of tailings are formed in the world due to increasing mining activities along with the increase in need for raw materials.

There are legal regulations about the disposal of the tailings in many countries. In Europe, the draft directive that regulates the management of the tailing was first published by the EU Commission in October, 2000 [1]. Today, the Regulation No. 596/2009/EC published in 2009 pursuant to the Directive No. 2006/21/EC of the European Union on the Management of Mine Tailing, the policy of the EU on mine tailing, aims to ensure long-term stability in disposal facilities, and reduce the negative effects of mining activities on the environment such as the leakage of acid, alkali drainage, and heavy metals. The EU legislation introduces certain minimum obligations, and aims to contribute to the protection of natural sources especially by promoting their recycling in order to improve the management of the tailing, and

Corresponding author: Atac Bascetin, professor, research fields: tailing management, paste technology and open-pit mine. taking into consideration the risks to the environment and human health. Furthermore, they require the Member States to take appropriate precautions in order to manage the tailing without any harm to the human health and the environment, leading to noise and smell, and affecting the areas and regions of particular importance therefore oblige the establishment owners to create tailing management plans that minimize the tailing resulting from mining activities, their processing, recycling, and disposal [2].

The tailing disposal methods used in mining industry can be classified into the type of tailing, the purpose of the method used, settlement, type of construction, and status of water discharge. Tailing dams, dry disposal, disposal in the open quarry, disposal in sea, lake, and river beds, surface paste tailing disposal, and tailing disposal using geotextile material are the primary surface tailing disposal methods. Even though tailing dams are the most used method for the disposal of mine tailings, they also bring many problems in terms of cost, environment, and human health. It is known that there are approximately 3,500 tailing dams around the world, and 138 important tailing dam accidents in total were 
reported as of 2012. Some of the environmental problems caused by tailing dams are presented in Table 1 [3-6].

As seen in Table 1, the accidents that may lead to big catastrophes for the environment and human health can take place unless sustainable, appropriate, correct, and sufficient precautions are taken in tailing dams. Furthermore, environmental problems such as AMD (acid mine drainage) and heavy metal mobilization can affect the lives of the living beings. AMD is formed as a result of the leaking of rainwater, and of the water that is formed as a result of mining activities into tailing containing sulphur mineral, their dissolution and oxidation of the sulphide formed. Furthermore, this situation leads to the spread of the heavy metals dissolved at low $\mathrm{pH}$ environment, and hence heavy metal mobilization takes place [7-9].

The studies on this subject have increased because of significant environmental problems in the tailing dams [10]. Environmental damages that occur during the disposal of mine tailing by using tailing dams above the ground can be significantly reduced using new technologies and methods. Nowadays, the safe disposal of the metal mine tailing that are generally discharged into surface tailing dams using paste tailing technology and tailing disposal using geotextile materials, which are among the disposal methods, the importance of which has gradually increased in recent years, have been investigated [11]. In this study, advantages and disadvantages of the methods of surface paste tailing disposal and tailing disposal using geotextile materials that have been developed as alternatives to the traditional tailing dam method were evaluated, and the operation and capital costs of these three methods in terms of a $\mathrm{Pb}-\mathrm{Zn}$ mine establishment were compared.

\section{Method}

The annual amount of the tailing used this study was determined as 1,250,000 tons in line with the data collected from the establishment, and the cost analyses were performed according to the tailing disposal life for 5 years. The cost items for each of these tailing disposal methods are presented in Table 2.

\subsection{Surface Paste Tailing Disposal}

Surface paste disposal method is one of the paste tailing technology applications along with underground paste fill. The paste tailing technology was first started to be used in Grund mine in Germany in the late 1970s in the form of fill for the purpose of underground fortification [12]. Especially, scientific studies on the surface and underground disposal of the paste material consisting of process tailing have gained pace since this date. The paste tailing technology

Table 1 Environmental problems caused by tailing dams [3-6].

\begin{tabular}{lll}
\hline Date & Place & Explanation \\
\hline 1985 & Italy & Tailing mud spread around as a result of the collapse of the tailing dam, and 268 people killed. \\
1992 & Kyrgyzstan & Harsh weather conditions lead to the damaging of the environment by seepage water. \\
1998 & Spain & $5,000,000 \mathrm{~m}^{3}$ of tailing mud spread around and 3,500 hectares of agricultural land. \\
2001 & Portugal & AMD risk emerged in the tailing dam. \\
2002 & Italy & Tailing mud was mixed with the seawater as the facility’s tailing was higher than the capacity of the dam. \\
2005 & China & Tailing mud leaked into a river due to the collapse of the tailing dam. \\
2006 & Zambia & Tailing mud leaked into a river due to the collapse of the tailing dam. \\
2008 & China & Tailing mud spread around due to the collapse of the tailing dam and 254 people killed. \\
2009 & Russia & 150.000 $\mathrm{m}^{3}$ of tailing spread around due to the collapse of the tailing dam. \\
2009 & China & Mud spread around with the collapse of the tailing dam. \\
2010 & Hungary & $700,000 \mathrm{~m}^{3}$ of tailing mud spread around due to the collapse of the tailing dam. \\
2011 & Turkey & The risk of the mixing of 25,000,000 $\mathrm{m}^{3}$ of cyanide water in the nature. \\
2011 & China & Tailing mud spread around. \\
2013 & Armenia & Tailing mud leaked into a river near the area for a few days due to the damaging of the dam. \\
2014 & Canada & $7,300,000 \mathrm{~m}^{3}$ of tailing mud was mixed with the lake due to the collapse of the tailing dam.
\end{tabular}


Table 2 Cost items of the tailing disposal methods.

\begin{tabular}{|c|c|c|c|c|}
\hline Cost & & Surface paste disposal & Tailing dam & Tailing disposal using geotextile material \\
\hline \multirow{7}{*}{ Capital cost } & Dam construction & $\mathrm{X}$ & $\mathrm{X}$ & - \\
\hline & Pump & $\mathrm{X}$ & $\mathrm{X}$ & $\mathrm{X}$ \\
\hline & Pipe & $\mathrm{X}$ & $\mathrm{X}$ & $\mathrm{X}$ \\
\hline & Thickener & $\mathrm{X}$ & - & - \\
\hline & Silo & $\mathrm{X}$ & - & - \\
\hline & Mixture tank & $\mathrm{X}$ & - & - \\
\hline & Land tax & $\mathrm{X}$ & $\mathrm{X}$ & $\mathrm{X}$ \\
\hline \multirow{7}{*}{ Operational cost } & Energy consumption & $\mathrm{X}$ & $\mathrm{X}$ & $\mathrm{X}$ \\
\hline & Labour & $\mathrm{X}$ & $\mathrm{X}$ & $\mathrm{X}$ \\
\hline & Maintenance & $\mathrm{X}$ & $\mathrm{X}$ & $\mathrm{X}$ \\
\hline & Cement & $\mathrm{X}$ & - & - \\
\hline & Flocculant & $\mathrm{X}$ & - & $\mathrm{X}$ \\
\hline & Geotextile tube & - & - & $X$ \\
\hline & Land cost & $\mathrm{X}$ & $\mathrm{X}$ & $X$ \\
\hline
\end{tabular}

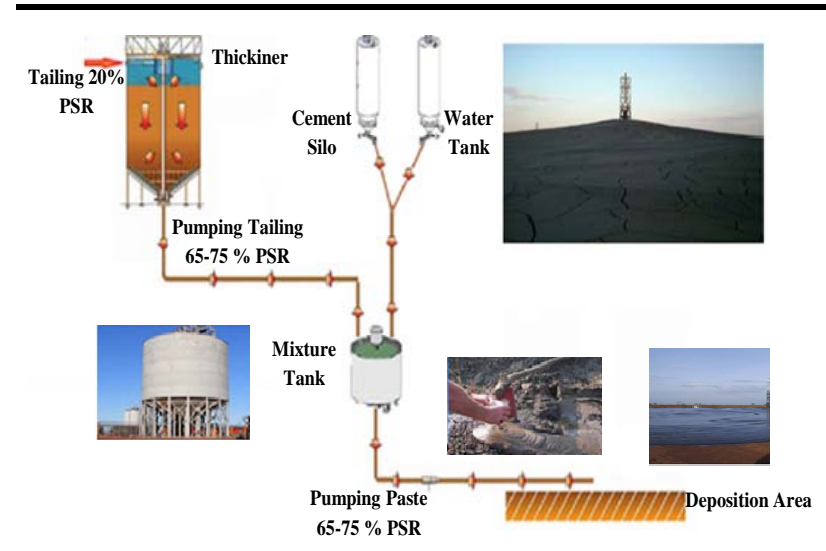

Fig. 1 Surface paste disposal application.

developed as an alternative to the surface disposal methods used in recent years is defined as a fine material with a texture pumpable by mixing with a certain amount of water and additional binding material where it is deemed necessary after dehydrating ore preparation plant tailings through filtration and thickening [13-16].

The applications of the surface tailing disposal method are shown in Fig. 1. As seen in Fig. 1, the tailing sample having 20\% PSR (pulp solid ratio) taken out of the ore preparation plant is first dehydrated up to 65-70\% PSR in the thickener, and then fed into the mixing tank by pumps. The residual material mixed with water and preferably binding material in the mixing tank is pumped to the tailing area in the form of a paste in $\sim 75 \%$ PSR using pumps once again. The design of surface paste disposal is firstly started obtaining of the mixing rate of the paste material. In the design of the mixture, it is required that the material can be pumpable, dry in an appropriate time, have sufficient strength, and spread to appropriate distances. Then, the disposal design is started, and it is required that the material does not constitute an environmental risk, and its mechanical properties are at the required level in the disposal design. Pump and transmission line should be designed after the construction of a disposal area with an appropriate capacity and strength. The flow rate, solid ratio, the transmission distance, pump head, viscosity, and yield stress of the paste material are effective in pump selection, and thus the cost of the pump.

In the literature, the material having up to $100 \mathrm{~Pa}$ of yield stress and between $60 \%$ and $73 \%$ PSR is qualified as a slurry while a material with a yield stress higher than $100 \mathrm{~Pa}$ and between 65\% and 85\% PSR is qualified as a paste. Slurry type pumps are used in the transmission of the slurry material. A piston diaphragm type pump with a yield stress in the interval of 100-250 Pa is used for thickened tailings and paste type material, while hydraulically actuated piston type pumps are used for the yield stress values that are higher than 250 Pa. The viscosity value, transmission distance, pump head, and flow rate of the material are taken into consideration in the determination of the power and number of the pumps [17-19]. It is necessary to define 
the height and diameter of the pumps to be used in the transmission line design. Pipe length values are determined for the establishment depending on the distance between the tailing area and ore preparation facility. The pipe diameter should be of a dimension that will enable the pulp to move in the pipe without depositing. The solid materials in the content of the pulp will deposit if the pulp in the pipe does not move at the sufficient speed. It is necessary for the pulp speed not to fall below a certain speed in order to the particles not to deposit, and this is called the critical settling speed. It is necessary for the critical speed calculated using the selected pipe diameter to be lower than the flow rate of the pulp.

\subsection{Tailing Dams}

Dams have been used for hundreds of years in order to control water. Tailing dams have started to be used as structures in which both water and tailings are gathered together in the mining industry since the beginning of the $20^{\text {th }}$ century. Thus, they are generally used in the operations in which the disposal of high volumes of water is planned. The dam must be designed in real dimensions, and the necessary calculations must have been made, and constructed in full capacity before starting any disposal activity. There are three main designs of tailing dams according to the method of bank construction. These designs are upward elevation, downward elevation, and elevation from the center. Upward elevation designs are the set designs with the lowest initial costs and the most widespread use. Although they are widespread and they look economical, they are the designs with the highest number of major environmental catastrophes around the world [20]. Downward elevation sets were derived in order to reduce the risks in upward elevation sets. They aim to reduce the defeats that occur under dynamic loads such as earthquakes [21]. Sets that elevate from the center are the combination of upward elevation sets and downward elevation sets [22]. They are more resistant when compared to upward elevation sets and they need less filling materials when compared to downward elevation sets. The application of the tailing dam method is shown in Fig. 2.

As seen in Fig. 2, the waste mud with 20\% PSR taken out of the ore preparation facility according to the tailing dam method is stored in the tailing dam with the help of pumps, and the tailing material deposits with its own weight, and the PSR becomes $\sim 60 \%$. Furthermore, the water that is collected in the upper section of the dam is fed to the facility again by water pumps. Firstly, the design of the tailing dam starts with the determination of the type of dam to be used (upward elevation, downward elevation, and elevation from the center). Pump and transmission line designs should be carried out after the construction of a tailing dam with an appropriate capacity and strength.

\subsection{Tailing Disposal Method Using Geotextile Material}

Geotextile material was first used in the field of dehydration in the 1970s, and then in mining in the 1980s. The tailing disposal method using geotextile material is based on the principle of pumping, dehydrating, and disposing of the tailing of the facility in a material called geotextile tube.

Geotextile tubes are produced with high strength, braided or not braided, and in required dimensions [23, 24]. The biggest advantage of this method is not to need forany disposal area [25]. The application of the tailing disposal using the geotextile material is shown in Fig. 3.

As seen in Fig. 3, the pulpat 20\% PSR is pumped into tubes by pumps, and the water that flows through

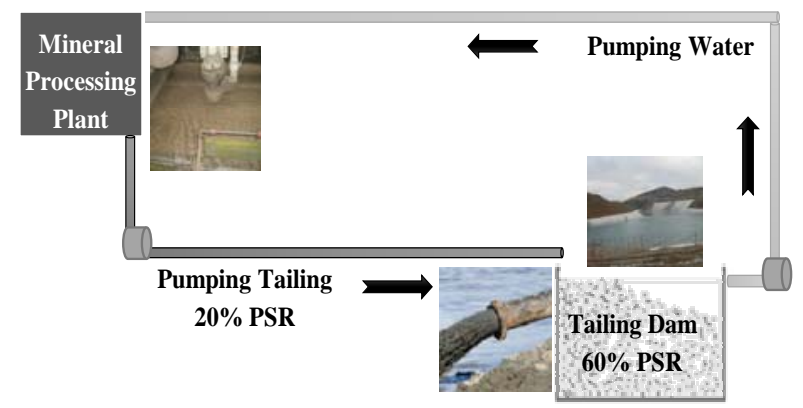

Fig. 2 Application of tailing dam. 


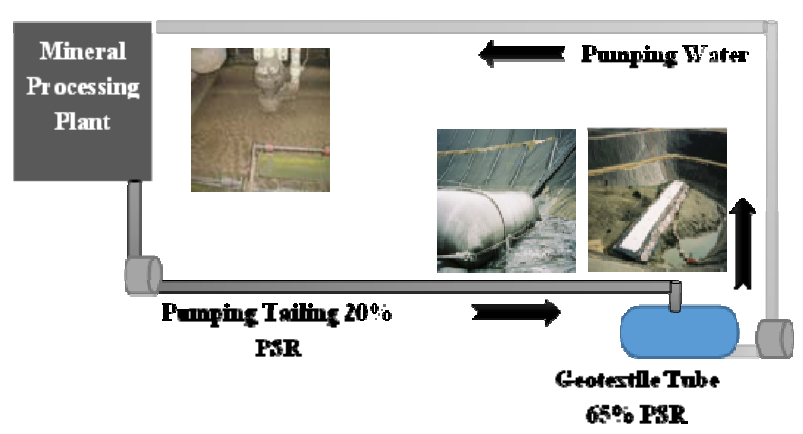

Fig. 3 Application of disposal using geotextile material.

the pores of the tube is fed into the plant once again. The design of the tailing disposal using the geotextile material first starts with determining which type of geotextile tube will be used. Here, the pore opening and strength of the geotextile tube are the parameters to take into consideration. Then, the type and amount of the flocculant is determined based on the size of very fine materials off the pores of geotextile tubes. The total cost increases in case of the excess use of the flocculant material while the fine material does not form a cake when it is used less amount. The pump and transmission line should be designed after the selection of the flocculants and geotextile tubes.

The methods of the surface paste tailing disposal and the disposal using the geotextile materials which are developed as alternatives to the traditional tailing dam method bring about many environmental advantages.
Accordingly, the advantages and disadvantages of these tailing disposal methodsare listed in Table 3 [11, 26, 27].

As also seen in Table 3, even though the methods of surface paste tailing disposal and tailing disposal using geotextile material have many advantages, the applications of these methods are more complicated compared to the traditional tailing dam method. Furthermore, the high cost of geotextile tubes increases the operating cost of this method.

\section{Results and Discussion}

Costs of tailing disposal that constitute a major part of the project capital cost are quite important in terms of the enterprises. Thus, the cost analysis should be carried out when the tailing disposal method is chosen. The cost analyses of the methods of surface paste tailing disposal and tailing disposal using geotextile material were performed for a model $\mathrm{Pb}-\mathrm{Zn}$ facility in the context of this study, and they were compared with the costs of the traditional tailing dam method. In the cost analyses, the usage life of the methods was considered as 5 years, and the topographical conditions of the model were taken into consideration. The operation and capital costs of 3 methods are shown in Fig. 4. The surface paste disposal method was given in

Table 3 Advantages and disadvantages of tailing disposal methods [11, 26, 27].

\begin{tabular}{|c|c|c|}
\hline Method & Advantages & Disadvantages \\
\hline Tailing dam & $\begin{array}{ll}\text { - } & \text { Tailings are usually produced by wet processes } \\
\text { - } & \text { Hydraulic transportation by pipeline to the disposal site } \\
\text { - } & \text { Practical application }\end{array}$ & $\begin{array}{ll}\text { - } & \text { Environmental problems } \\
\text { - } & \text { Accidents related to the waste dam } \\
\text { - } & \text { High reclamation cost } \\
\text { - } & \text { Climatic conditions } \\
\end{array}$ \\
\hline $\begin{array}{l}\text { Surface paste } \\
\text { disposal }\end{array}$ & $\begin{array}{ll}\text { - } & \text { Increased security } \\
\text { - } & \text { Facilities of reclamation to be better than conventional methods } \\
\text { - } & \text { Reduction of the negative public perception } \\
\text { - } & \text { Smaller disposal site (for the same amount) } \\
\text { - } & \text { Protection of water resources (water-saving) } \\
\text { - } & \text { Reduction of soil and groundwater contamination } \\
\text { - } & \text { Reduction of Miner's obligation as tuition payments } \\
\text { - } & \text { Very little leachate water } \\
\text { - } & \text { Non-segregation of particles in pipe line } \\
\text { - } & \text { Rapid drainage of rainwater } \\
\end{array}$ & $\begin{array}{l}\text { - } \quad \text { Paste production may lead to extra } \\
\text { costs } \\
\text { - } \quad \text { Not practical application }\end{array}$ \\
\hline $\begin{array}{l}\text { Tailing disposal } \\
\text { using geotextile } \\
\text { materials }\end{array}$ & $\begin{array}{ll}\text { - } & \text { Environmental concerns } \\
\text { - } & \text { Reduction of capital costs } \\
\text { - } & \text { Low reclamation cost } \\
\text { - } & \text { Climatic conditions not affected } \\
\end{array}$ & - $\quad$ High operational cost \\
\hline
\end{tabular}


two forms as with and without cement.

As also seen in Fig. 4, total costs of the tailing dam and the surface paste disposal methods were calculated as $\sim 14,000,000 \$$. In the case of cement it is used for the surface paste disposal method, the operation cost rises from $\sim 9,000,000 \$$ to $\sim 12,000,000 \$$, and this makes the calculated total cost of $\sim 17,000,000 \$$ to be higher than the total cost of the tailing dam method. As more tailing disposal areas are needed for the tailing dam method, a higher capital cost is in question when compared to other methods. However, the operation cost is lower than in other methods. While the capital costs for the tailing disposal using the geotextile material method is lower than that of the other methods with $\sim 1,000,000 \$$, the operation, and thus the total cost of this method is quite high with $\sim 46,000,000 \$$ because of the high cost of the geotextile tubes. The distribution of the capital cost units of the methods in question is shown in Fig. 5.

As also seen in Fig. 5, the cost of the tailing dam construction has the highest cost among the total capital costs, and constitutes $\sim 81 \%$ of the total capital cost. The cost of the land comes after the cost of the

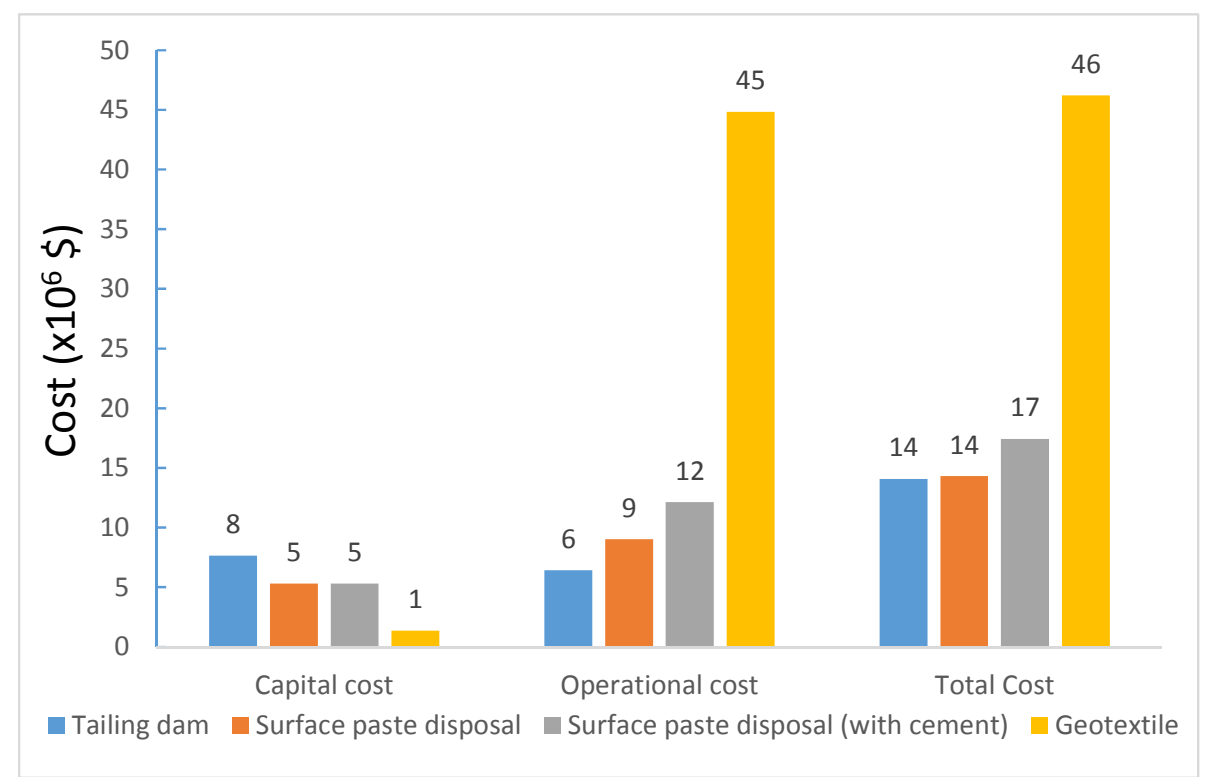

Fig. 4 Operation and capital costs for the 3 methods.

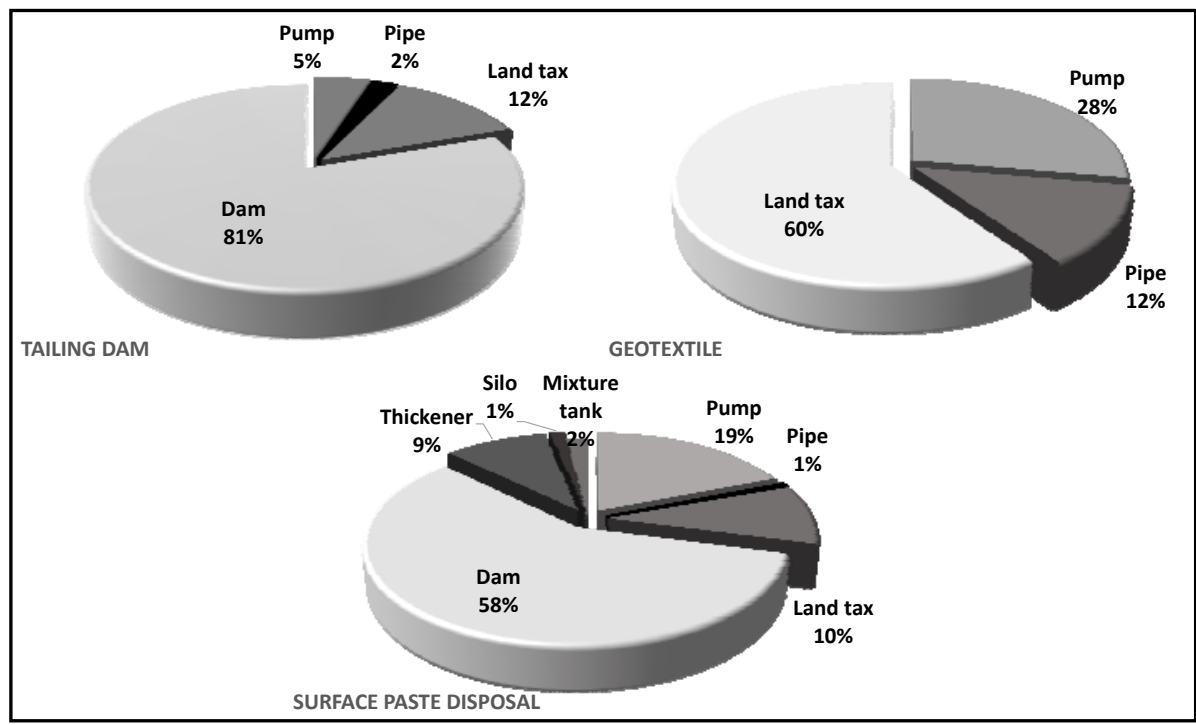

Fig. 5 Distribution of the capital cost units of the 3 methods. 
construction of the tailing dam, and makes up $~ 12 \%$ of the total capital cost. The cost of disposal area construction is the highest cost item among the total capital costs for the surface paste disposal method, and makes up $\sim 58 \%$ of the total capital cost. The pump cost comes after the cost of the disposal area construction, and makes up $\sim 19 \%$ of the total capital cost. In the method of the disposal using the geotextile material, the land cost is the highest cost, item among the total capital costs and makes up $\sim 60 \%$ of the total capital cost. The pump cost comes after the land cost, and makes up $\sim 28 \%$ of the total capital cost. The distribution of the operational cost items is shown in Fig. 6.

As also seen in Fig. 6, land permission cost is the highest cost item in the total operation cost for the total tailing dam method and makes up $\sim 48 \%$ of the total operation cost. The energy consumption cost comes after the land permission cost, and makes up 36\% of the total operation cost. In the case of the surface paste disposal method, the energy consumption cost within the total operation costs in the absence of cement is the highest cost item, and makes up $\sim 49 \%$ of the total operation cost. The flocculant cost comes after the energy consumption cost, and makes up 21\% of the total operation cost. The cost of energy consumption is the highest cost item once again in the presence of cement, and makes up $~ 36 \%$ of the total operation cost. The cement cost comes after the energy consumption cost, and makes up $\sim 26 \%$ of the total operation cost. In the method of disposal using geotextile material, the geotextile tube cost is the highest cost item in the total operation cost, and makes up $\sim 79 \%$ of the total operation cost. The land permission cost comes after the geotextile tube cost, and makes up 9\% of the total operation cost. The unit costs per ton of these methods are shown in Fig. 7.

As also seen in Fig. 7, the unit costs of the tailing dam and the surface paste disposal methods were calculated as 2.25 \$/ton and 2.29 \$/ton, respectively. These values are very close to each other, but the unit cost of the surface disposal method is 2.79 \$/ton when cement is used. Environmental legislations and the differences in the designs may change these cost values. For example, the unit cost of the tailing dam was found as 0.5-1.2 \$/ton for a gold mine [28]. In the case of the tailing disposal method using the geotextile material, the unit price is quite high with $7.39 \$ /$ ton as a result of the high cost of geotextile tubes $\left(0.66 \$ / \mathrm{m}^{3}\right)$.

As also seen from the cost analyses, the costs of the

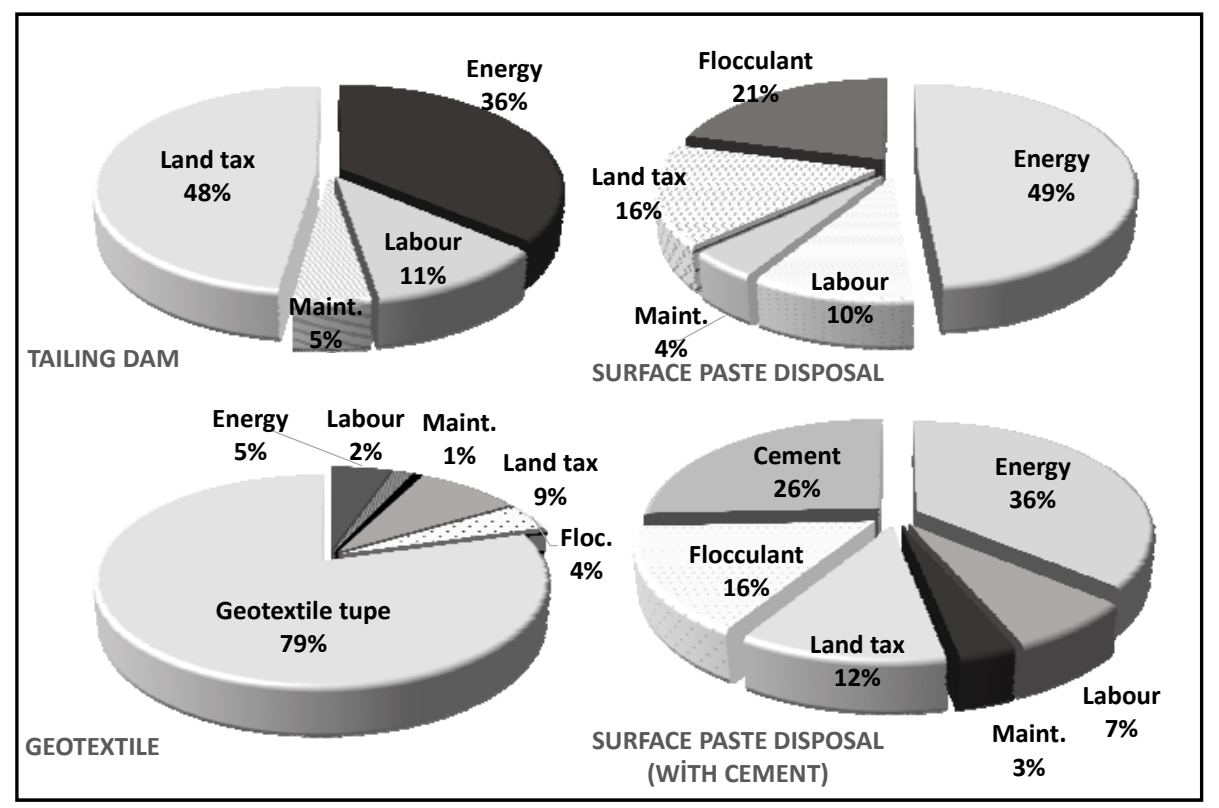

Fig. 6 Distribution of the operation cost items of the 3 methods. 


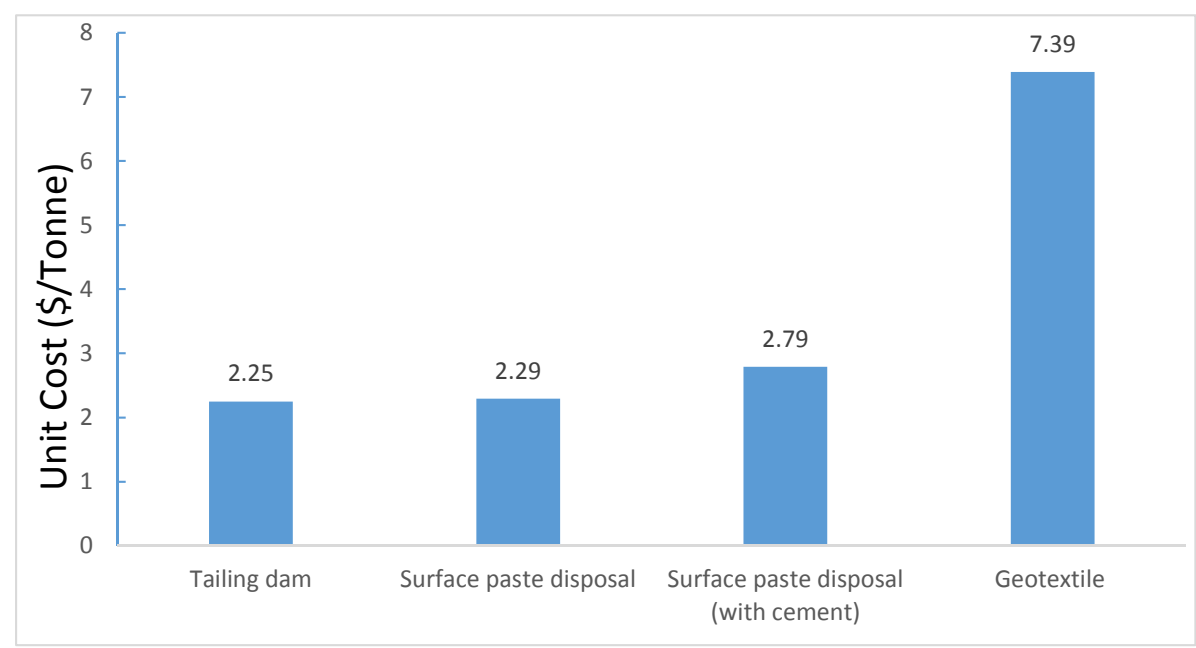

Fig. 7 Unit costs of the 3 method.

tailing dam and surface paste disposal methods are close to each other. However, the tailing dam method is simple when compared to the surface paste disposal and disposal using the geotextile material method in terms of design and application. Many tests should be conducted at the laboratory and field while performing the surface paste disposal. The most important ones among them are the slump and rheology experiments conducted at the stage of paste material mix design, and $\mathrm{pH}$ measurements carried out on matric suction, oxygen consumption, and seepage water at the stage of disposal design. The type of the pump to be used in the transfer of paste material and the flow behaviors of the material in the disposal area are determined using the slump and rhelogy experiments. The AMD formation risk of the paste material stored above the ground is determined measuring of the $\mathrm{pH}$ of seepage water. In the case of tailing disposal method using the geotextile material, dehydration experiments with regard to geotextile tubes should be performed, and which type of geotextile tube is suitable for the tailing material should be determined at the stage of design. Another important experiment is the sedimentation experiment in order to obtain the optimum flocculant dosage. Thus, first the designs of the methods of surface paste and disposal using geotextile material which have many environmental advantages should be fully revealed by experimental studies before applying them in the field.

\section{Conclusions}

Taking sustainable, appropriate, correct, and sufficient precautions in the tailing management before and after mining activities can minimize and even eliminate the negativities that can occur. In case no sustainable tailing method is applied, the disposal of huge amounts of tailing by a not-well defined method brings about environmental and economic disadvantages in terms of the mining management. Recently, several methods, namely, dry tailings, thickened tailings, co-disposal of tailings, surface paste disposal, and tailing disposal using geotextile material have been developed for safely disposal of mill plants tailings. Among these methods, surface paste disposal and tailing disposal using geotextile material offer many advantages for tailings management systems in environmental aspects. Within this framework, various researchers have studied this subject in order to apply alternative methods more economically together with the developing technology.

In this study, the disposal methods with tailing dam, surface paste disposal, and tailing disposal using geotextile material methods were compared, and the capital costs, operation costs, and total costs of these methods with a life of 5 years were calculated. Accordingly, the methods with the lowest total capital cost are disposal using the geotextile material, surface paste disposal, and tailing dam, respectively. Here, the 
cost of disposal area constructions and land costs related to this constitute the most important share of capital cost. By contrast, the methods with the lowest operation cost are the tailing dam disposal method, surface paste disposal method, and disposal using geotextile material, respectively. The reason for the excessive cost increase in operation costs in the disposal method using geotextile material is the high cost of geotextile tubes. That the cost of geotextile tubes must be lower in order to be more economical when compared to other methods was revealed in the context of this study. Furthermore, the total cost of the surface paste disposal method that has many advantages in terms of environmental risks and strength is very close to the total cost of the tailing dam method when cement is not used. Hence, it can be concluded that the surface paste disposal method is the most appropriate method for the tailings disposal on surface in economic terms.

\section{References}

[1] Cetiner, E. G., Unver, B., and Hindistan, M. A. 2006. "Regulations Related with Mining Wastes: European Community and Turkey.” Mining 45-1: 23-34.

[2] CPS. 2012. "European Union Guide about Tailing Management.” A report prepared for Mess: 1-97.

[3] Vogt, C. 2012. "International Assessment of Marine and Riverine Disposal of Mine Tailings.” A Report Prepared for LC/LP, IMO and UNEP GPA: 1-134.

[4] Cadden, A., Newman, P., and Fordham, M. 2003. "New Developments in Surface Paste Disposal of Mine Wastes.” Proceedings of Disposal Minerals Industry, June 2003, London.

[5] Bascetin, A., Tuylu, S., Adiguzel, D., and Akkaya, U. G. 2014. "The Study of Surface Paste Disposal Technology for Pb-Zn Mine Tailings.” SME Annual Meeting, Preprint 14-020, Feb. 23-26, 2014, Salt Lake City, UT-USA.

[6] Bowker, L. M., and Chamber, D. M. 2015, The Risk, Public Liability, \& Economics of Tailings Storage Facility Failures. Report, July 21, 1-56.

[7] Nehdi, M., and Tariq, A. 2007. "Stabilization of Sulphidic Mine Tailings for Prevention of Metal Release and Aid Drainage Using Cementitious Materials: A Review.” J. Environ. Eng. Sci. 6: 423-36.

[8] Bascetin, A., Tuylu, S., Adiguzel, D., Akkaya, U., and Binen, I. S. 2013. "Investigation of Suitability of $\mathrm{Pb}-\mathrm{Zn}$ Mine Tailings for Surface Paste Disposal.” 23rd World
Mining Congress, Montreal, CANADA, August 11-15, 301.

[9] Verburg, R. B. M. 2002. "Paste Technology for Disposal of Acid-Generating Tailings.” Mining Environmental Management 13-7: 14-8.

[10] Sofra, F., and Boger, D. V. 2001. "Environmental Rheology for Waste Minimisation in the Minerals Industry." Chemical Engineering Journal 86: 319-30.

[11] Bascetin, A., Ozdemir, O., Tuylu, S., Adiguzel, D., and Akkaya, U. G. 2015a. "Storage of Mining Processing Tailings at Surface Using Paste Technology.” MT Scientific Journal of Underground Resources: 33-49.

[12] Grice, A. 1998. “Underground Mining with Backfill.” The 2nd Annual Summit-Mine Tailings Disposal Systems, Brisbane.

[13] Brackebusch, F. W. 1994. "Basics of Paste Backfill Systems.” Mining Engineering 46: 1175-8.

[14] Newman, P., Cadden, A., and White, R. 2001. "Paste-The Future of Tailings Disposal?" Securing the Future, International Conference on Mining and the Environment, June 25-July 1, Skelleftea, Sweden, 594-603.

[15] Verburg, R. B. 2001. "Use of Paste Technology for Tailings Disposal: Potential Environmental Benefits and Requirements for Geochemical Characterization.” IMWA Symposium.

[16] Theriault, J., Frostiak, J., and Welch, D. 2003. "Surface Disposal of Paste Tailings at the Bulyanhulu Gold Mine.” Proceedings of the 2nd Mining Environment Conference, Sudbury, Ontario, 1-8.

[17] Cooke, R. 2008. "Pipeline Design for Paste and Thickened Tailings Systems.” Tailings and Mine Waste 2008.

[18] Spiers, J. 2010. "Rheological and Geotechnical Characteristics.” Methods for Treatment of Mine Tailings: 16-7.

[19] Hustrulid, W. A., and Bullock, R. L. 2001. "Underground Mining Methods: Engineering Fundamentals and International Case Studies.” SME, 2001-Technology \& Engineering, 718.

[20] Davies, M. P., Martin, T. E., and Lighthall, P. 2000. "Mine Tailings Dams: When Things Go Wrong.” Tailings Dams 2000, Association of State Dam Safety Officials, U.S. Committee on Large Dams, LasVegas, Nevada: 261-73.

[21] ICOLD and UNEP. 2001. "Bulletin 121: Tailings Dams-Risk of Dangerous Occurrences.” Lessons Learnt from Practical Experiences. Paris: 44.

[22] Benckert, A., and Eurenius, J. 2001. "Tailings Dam Constructions." Seminar on Safe Tailings Dam Constructions. Gallivare, Swedish Mining Association, Natur Vards Verket, European Commission, 30-6.

[23] Bascetin, A., Ozdemir, O., Adiguzel, D., Tuylu, S., Baktarhan, Y., and Hamstel, M. T. 2015b. "Use of Geoextıle Filtratıon System (Geotube ${ }^{\circledR}$ Technology) for 
Dewaterıng and Disposal of Mıneral Processing Plant Tallıngs.” XVI Balkan Mineral Processing Congress, Belgrade-Serbia, June 17-19.

[24] Palmeira, E. M., Beirigo, E. A., and Gardoni, M. G. 2010. "Tailings-nonwoven Geotextile Filter Compatibility in Mining Applications.” Geotextiles and Geomembranes 28: 136-48.

[25] Newman, P., Hodgson, M., and Rosselot, E. 2004. "The Disposal of Tailings and Minewater Sludge Using Geotextile Dewatering Techniques.” Minerals Engineering 17: 115-21.
[26] Fourie, A. B. 2003. "In Search of the Sustainable Tailings Dam: Do High-Density Thickened Tailings Provide the Solution.” School of Civil and Environmental Engineering, University of the Witwaterstrand, South Africa: 12.

[27] Welch, D. 2003. "Advantages of Tailings Thickening and Paste Technology.” Responding to Change-Issues and Trends in Tailings Management-Golder Associates Report: 5.

[28] Leduc, M., and Smith, M. E. 2003. "Tailings Co-Disposal: Innovations for Cost Savings and Liability Reduction.” Vector Engineering Inc: 9. 